\title{
A nemszteroid gyulladáscsökkentő gyógyszerek kiválasztásának szempontjai a biztonságosság tükrében
}

\author{
Szamosi Szilvia dr. \\ Debreceni Egyetem, Általános Orvostudományi Kar, Belgyógyászati Intézet, Reumatológiai Tanszék, Debrecen
}

\begin{abstract}
A nemszteroid gyulladáscsökkentő gyógyszerek a leggyakrabban javasolt fájdalomcsillapítók. A reumatológiai gyakorlatban a fájdalom és a gyulladás csökkentésére egyaránt használjuk, ugyanakkor a terápiás ajánlások is fokozott óvatosságra intenek e gyógyszercsoport használata során, azok jól ismert lehetséges - gastrointestinalis, cardiovascularis és renalis - mellékhatásai miatt. Különösen igaz ez az idősebb életkorú vagy fiatalabb, de polimorbid betegek esetében. Miután hazánkban is öregedő populációval kell számolnunk, alapvető fontosságú, hogy a gyakorló orvos tisztában legyen a nemszteroid gyulladáscsökkentők alapvető farmakokinetikai sajátosságaival, gyógyszer-interakcióival, mellékhatásprofiljával, és a saját szakterületén belül mindig a legújabb irányelvek mentén használja ezeket a gyógyszereket.
\end{abstract}

Orv Hetil. 2018; 159(44): 1783-1788.

Kulcsszavak: fájdalomcsillapítás, mellékhatás, nemszteroid gyulladáscsökkentő

\section{Recommendation for the substantial choice between various nonsteroidal antiinflammatory drugs based on their safety profile}

\begin{abstract}
Nonsteroidal antiinflammatory drugs are the most commonly used painkillers. Both analgetic and antiinflammatory effects of these medications are important in the treatment of rheumatic diseases. Despite their well-recognized efficacy, professional societies recommend using nonsteroidal antiinflammatory drugs with caution, balancing the various potential gastrointestinal, cardiovascular and renal adverse events. Clinicians should consider advanced age and history of concomitant diseases even in younger patients when considering treatment choice. As our Hungarian society is aging, prescribers must be aware of the basic pharmacodynamics and pharmacokinetics of nonsteroidal antiinflammatory drugs as well as drug interactions and potential adverse effects should be taken into consideration when using them according to the latest professional guidelines.
\end{abstract}

Keywords: pain management, side effect, nonsteroidal antiinflammatory drug

Szamosi Sz. [Recommendation for the substantial choice between various nonsteroidal antiinflammatory drugs based on their safety profile]. Orv Hetil. 2018; 159(44): 1783-1788.

(Beérkezett: 2018. augusztus 30.; elfogadva: 2018. szeptember 19.)

\begin{abstract}
Rövidítések
ACR $=($ American College of Rheumatology) Amerikai Reumatológiai Kollégium; CLASS $=($ Celecoxib Long-term Arthritis Safety Study) celekoxib hosszú távú biztonságossági vizsgálata arthritisben; $\mathrm{COX}=($ cyclooxygenase $)$ ciklooxigenáz; $\mathrm{CS}=$ (corticosteroid) kortikoszteroid; $\mathrm{CV}=$ cardiovascularis; EMA = (European Medicines Agency) Európai Gyógyszerészeti Ügynökség; EULAR = (European League Against Rheumatism) Európiai Reumatológiai Társaság; FDA $=($ U.S. Food and
\end{abstract}

Drug Administration) az Amerikai Egyesült Államok Élelmiszer-biztonsági és Gyógyszerészeti Hivatala; GI = gastrointestinalis; $\mathrm{MI}=$ myocardialis infarctus; NSAID $=$ (nonsteroidal antiinflammatory drug) nemszteroid gyulladáscsökkentő gyógyszer; $\mathrm{OA}=$ osteoarthrosis; $\mathrm{OR}=$ (odds ratio) esélyhányados; PGE2 = prosztaglandin E2; PGI2 = prosztaglandin I2; $\mathrm{PPI}=$ (proton-pump inhibitor) protonpumpagátló; PRECISION $=$ (Prospective Randomized Evaluation of Celecoxib Integrated Safety versus Ibuprofen or Naproxen) pros- 
pektív randomizált vizsgálat a celekoxib biztonságosságára ibuprofénnel és naproxénnel összehasonlítva; RA = rheumatoid arthritis; TAG = thrombocytaaggregáció-gátló; TXA2 = thromboxane A2; $\mathrm{WHO}=$ (World Health Organization) Egészségügyi Világszervezet

A nemszteroid gyulladáscsökkentő gyógyszerek (NSAIDok) a legjobb fájdalomcsillapító és gyulladáscsökkentő potenciállal rendelkező szerek közé tartoznak, így nem meglepő, hogy a statisztikák alapján ezek a vényre rendelt leggyakoribb fájdalomcsillapítók, és az éves szinten felírt összes gyógyszer 5-10\%-át is az NSAID-ok teszik ki. A háziorvosi praxisban a 65 év feletti betegek 96\%ban használnak hosszabb-rövidebb ideig NSAID-ot, de akut mozgásszervi panaszok (például derékfájás, alagútszindrómák, sportsérülések stb.) esetén vagy gyulladásos és autoimmun betegségekben a fiatalabb populációban is általában ez az elsőként javasolt gyógyszeres terápia [1].

\section{Az NSAID-ok hatásmechanizmusa és metabolizmusa}

Az NSAID-ok antiinflammatorikus, analgetikus és antipiretikus hatása végső soron a ciklooxigenáz (COX) enzim reverzibilis gátlásának a következménye. A sejtmembrán foszfolipid komponenseiból a foszfolipáz A2 enzim hatására arachidonsav szabadul fel, majd a COX enzim hatására prosztaglandin E2 (PGE2) keletkezik, mely a gyulladásos folyamatok egyik fó mediátora. A ciklooxigenáz enzim két, elkülöníthető izomerrel rendelkezik, a COXl-gyel és a COX2-vel. Míg a COX2 fontosabb szerepet tölt be a prosztaglandin mediálta fájdalom és gyulladás kialakulásában, addig a COXI inkább úgynevezett 'housekeeping' funkciót lát el, és számos fiziológiás folyamat, így például a gyomormucosa védelmének vagy a vese vérellátásának a szabályozásában is szerepet játszik. Az NSAID-ok különböző mértékben, de mind a COXl, mind a COX2 izoenzimeket gátolják, ezáltal csökken a gyulladásos mediátorok koncentrációja $[2,3]$. A COXl izoenzimek gátlása felelős a mellékhatások többségéért (1. táblázat), a gyógyszercsoport legfő́bb kockázata a gyomor-bél rendszeri fekély és vérzés kialakulása. Emellett nem elhanyagolható a nephrotoxicitasuk és májkárosító hatásuk, melyek szintén fokozott figyelmet igényelnek. Ugyanakkor mind a tradicionális NSAID-ok, mind a szelektívebb COX2-gátló gyulladáscsökkentők alkalmazása esetén új, következményeiben jelentôs nemkívánatos hatásként jelent meg a cardiovascularis (CV) és cerebrovascularis kockázat (thromboticus események, köztük myocardialis infarctus, stroke) növekedése $[1,4]$.

A legtöbb NSAID jól felszívódik a gastrointestinalis (GI) traktuson keresztül, miáltal a biológiai hasznosulásuk is kiváló. Bizonyos hatóanyagú gyógyszerek (például diklofenák) esetében az elérhetőségüket csökkenti a máj 'first-pass' metabolizmusa, míg más molekulák inaktív,
1. táblázat A nemszteroid gyulladáscsökkentők lehetséges mellékhatásspektruma

\begin{tabular}{l|l}
\hline $\begin{array}{l}\text { Gastrointestinalis } \\
\text { (GI) mellékhatások }\end{array}$ & $\begin{array}{l}\text { Dyspepsia } \\
\text { Gyomor- és nyombélfekély } \\
\text { GI vérzés, perforáció }\end{array}$ \\
\hline $\begin{array}{l}\text { Cardio- és } \\
\text { cerebrovascularis } \\
\text { mellékhatások }\end{array}$ & $\begin{array}{l}\text { Ödéma } \\
\text { Hipertenzió } \\
\text { Pangásos szívelégtelenség } \\
\text { Myocardialis infarctus }(\mathrm{MI}) \\
\text { Stroke vagy egyéb thromboticus esemény }\end{array}$ \\
\hline Vesetoxicitas & $\begin{array}{l}\text { Az elektrolit-háztartás zavara } \\
\text { Nátriumretenció } \\
\text { Ödéma } \\
\text { Csökkent glomerularis filtrációs ráta (GFR) } \\
\text { Nephrosisszindróma } \\
\text { Akut interstitialis nephritis } \\
\text { Vesepapilla-necrosis } \\
\text { Krónikus vesebetegség/veseelégtelenség }\end{array}$ \\
\hline
\end{tabular}

úgynevezett 'prodrug' formában kerülnek be a szervezetbe, és a májban metabolizálódnak aktív hatóanyaggá (például szulindak-szulfid). Az NSAID-molekulák magas affinitással kötődnek a plazmaproteinekhez. Metabolizmusuk döntően a májban zajlik, és a vizelettel választódnak ki. Az egyes hatóanyagok fél életideje igen különböző lehet; a spektrum egyik végén az aszpirin áll $0,25-0,3$ órás, a másik végén a piroxikám $45-50$ órás időtartammal. Ezek a farmakokinetikai és farmakodinámiai paraméterek természetesen változhatnak a szervezet folyadék-összetételétól és fehérjetartalmától függően, például idősebb életkorban vagy szervi károsodások esetén [5].

\section{Az NSAID-ok használatára vonatkozó szakmai útmutatók}

Az Egészségügyi Világszervezet (WHO) által javasolt lépcsőzetes fájdalomcsillapítási modell 1986 óta használatban van az onkológiai gyakorlatban a daganatos fájdalom csillapítására, és ugyanúgy használjuk a mozgásszervi fájdalom esetében, elsősorban az akut fájdalom csillapítására. Enyhébb fájdalmak esetében ennek első lépcsőjét a nem opioid analgetikumok, az NSAID-ok képezik. A fentiek mellett előnyösebb a használatuk gyulladásos eredetû́ fájdalmak (például arthritisek) esetében - a gyengébb analgetikus hatású acetaminofennel szemben - az NSAID-ok antiinflammatorikus potenciálja miatt [6]. A mozgásszervi fájdalom csillapítására használt NSAID-ok alkalmazására vonatkozóan mindkét reumatológiai szakmai társaság (Amerikai Reumatológiai Kollégium - ACR; Európiai Reumatológiai Társaság EULAR) egyöntetúen fogalmazza meg álláspontját, és egyúttal óvatosságra int. Általában a legalacsonyabb effektív dózis alkalmazását a lehető legrövidebb ideig ajánlott folytatni, és a rendszeres betegmonitorozás is részét kell, hogy képezze a kezelésnek a potenciális mellékhatások mihamarabbi felismerése érdekében [7]. Krónikus 
fájdalom kezelésére alapvetően nem ajánlott NSAID-ot adni a GI mellékhatások előfordulásának fokozott rizikója miatt. Az egyik leggyakoribb krónikus mozgásszervi kórkép, az osteoarthrosis (OA) kezelésében a multimodális terápia részeként szintén jól meghatározott indikációval rendelkeznek a rövid ideig orálisan alkalmazott NSAID-ok [1]. Felvetődik tehát a kérdés, hogy amikor szükséges adni, mégis milyen NSAID-ot válasszunk a beteg számára?

Miután a klinikai vizsgálatok tanúsága alapján a szelektív és nemszelektív NSAID-ok hatékonysága összemérhető, a választást elsősorban az egyes készítmények lehetséges mellékhatásprofilja határozza meg, a beteg rizikófaktorainak felmérése után. A klinikai paraméterek mint rizikófaktorok közül az alábbiak figyelembevétele fontos: a beteg életkora (65 év felett/alatt), az anamnézisben fellelhető GI események (nyelőcső-, gyomorvagy duodenalis fekély, vérzés, obstrukció vagy perforáció) előfordulása, CV és stroke-rizikó, kis dózisú aszpirin szedése, antikoaguláns vagy egyéb, thrombocytaaggregációt gátló (TAG) gyógyszer vagy szisztémás kortikoszteroid (CS) használata [8].

\section{A szelektív COX2-gátlók használata}

A legtöbb tradicionális NSAID nemszelektív módon gátolja a COXl és COX2 enzimeket. A szelektív COX2gátlók közül korábban az FDA a celekoxib, etorikoxib, lumirakoxib, rofekoxib és valdekoxib hatóanyagú gyógyszereket engedélyezte rheumatoid arthritis (RA), OA és akut fájdalom kezelésére, azonban a rofekoxibot és a valdekoxibot az adverz CV események (ödéma, myocardialis infarctus, thromboticus események, stroke, hypertonia) gyakoribb előfordulása miatt, a lumirakoxibot pedig hepatotoxicus mellékhatásai miatt vonták ki a forgalomból [4]. A szelektív COX2-gátlók legfőbb előnye, hogy adagolásuk mellett a GI mellékhatások előfordulása alacsonyabb. Egy 688 rheumatoid arthritises beteget felölelő vizsgálatban 12 hetes követési idő alatt a celekoxib és a naproxén hasonló mértékben csökkentette az arthritises panaszokat a placebokezeléshez képest, ugyanakkor az endoszkópiával igazolt gastroduodenalis fekélyek előfordulási aránya hasonló volt a celekoxib- (4\%) és a placebokarban, de alacsonyabb volt, mint a naproxénnel kezeltekben (26\%) [9]. Egy másik, 8059 beteget vizsgáló prospektív tanulmányban, a CLASS vizsgálatban a 6 hónapos megfigyelési idő alatt a celekoxibkezelés mellett szignifikánsan alacsonyabb volt a fekélyek előfordulása az ibuprofénnel vagy diklofenákkal kezeltekhez képest [10]. A COX2-gátlók additív pozitív hatása, hogy a colorectalis daganatok rizikóját is csökkentik. Ennek hátterében az áll, hogy a humán colondaganatsejtek fokozott mértékben expresszálják a COX2-t, melynek aktivációja a tumor növekedését segíti elő. A COX2-inhibíció így részben a tumorsejtek proliferációjának gátlása, részben az apoptózisának elősegítése révén gátolja a tumor növe- kedését [11]. További előnyei a COX2-gátló szereknek, hogy a thrombocytafunkciót szignifikánsan nem befolyásolják, így alkalmazásuk előnyösebb lehet antikoagulált betegek gyulladásgátló kezelésére, és az aszpirinindukált asztmás betegeknek is biztonsággal adhatók, mert nem provokálnak bronchospasmust [12]. Az érem másik oldala a COX2-gátlók potenciális toxicitása, melyet a számtalan pozitív hatásuk mellett sem hagyhatunk figyelmen kívül. A legfőbb kockázati csoportot a CV eseményen átesett betegek jelentik. A COX2 enzimnek fontos szerepe van a vasculaturaprotectiv prosztaglandin I2 (PGI2) szintézisében, míg a thrombocyták prothromboticus tromboxán A2 (TXA2) szintézisét kevésbé befolyásolják. Az atheroscleroticus plakkot infiltráló macrophagokban fokozott mértékben expresszálódik a COX2, melynek gátlása a plakk instabilitásához és fokozott $\mathrm{CV}$ rizikóhoz vezet [13]. A CV szövődmények közül a MI, a stroke, a szívelégtelenség, a pitvarfibrilláció és a hirtelen szívhalál kockázata magasabb, de mint később látni fogjuk, ez egyaránt emelkedett a szelektív és a nemszelektív NSAID-ok használatakor, elsősorban a korábban $\mathrm{CV}$ eseményen átesett vagy fokozott rizikójú betegek esetében [14]. A COX2-gátló celekoxib használatát föként olyan válogatott esetekben ajánlják, amikor az alternatív nemszelektív NSAID-ok (például naproxén) vagy egyéb analgetikumok alkalmazása kontraindikált, például antikoagulált vagy korábban GI vérző betegek esetében. Az alacsony dózisú celekoxib $(<2 \times 200 \mathrm{mg}$ napi dózis) alkalmazása mellett a $\mathrm{CV}$ rizikó hasonló, mint a nemszelektív NSAID-ok esetében [15]. Egy 2013-as metaanalízis (több randomizált vizsgálatban részt vevő 88367 beteg) a koxibok mellett jelentkező major vascularis adverz események rizikóját hasonlította össze egyéb nemszelektív NSAID- és placebokezeléssel. A celekoxib mellett, dózisdependens módon, magasabb rizikót találtak (RR: 1,36) a placebóhoz képest [16]. A 24081 beteget involváló PRECISION vizsgálatban a naproxén ( $2 \times 375-500 \mathrm{mg})$, az ibuprofén $(3 \times 600-800 \mathrm{mg})$ és a celekoxib $(2 \times 100-200 \mathrm{mg})$ esetében hasonló volt az OA-s és RA-s betegek CV rizikója. Az analízisektől függően átlagosan 2-5\% volt a $\mathrm{CV}$ események előfordulási gyakorisága a követési periódusban [17]. Más a helyzet akkor, ha közvetlenül a coronariabetegség után részesül a beteg celekoxibkezelésben. Egy dán nemzeti kohorszvizsgálatban 4000, myocardialis infarctuson átesett beteg esetében szignifikánsan magasabb arányban jelentkezett 14-30 napon belüli reinfarktus vagy haláleset azoknál, akiknek a hospitalizációs periódusban koxibot írtak fel. A CV rizikó abban az esetben is emelkedett, ha a betegek TAG- vagy antikoaguláns kezelésben részesülnek [18]. A másik, Magyarországon is forgalomban lévő koxib, az etorikoxib alkalmazása mellett szintén magasabb CV rizikó állapítható meg, mely megegyezik egyéb nemszelektív NSAID-okéval. Három randomizált vizsgálatban részt vevő 35000 beteg adatai alapján a thromboticus $\mathrm{CV}$ események előfordulása között nem volt szignifikáns különbség az etorikoxibbal (1,24/100 ezer 
betegév) és diklofenákkal (1,3/100 ezer betegév) kezeltekben, de összességében magasabb rizikót találtak [14, 19].

\section{A nemszelektív NSAID-ok használata}

Az NSAID-ok hatásmechanizmusának tárgyalása kapcsán említettük, hogy a COXI enzim hatására prosztaglandin és tromboxán A2 képző́dik, melyek a GI traktus mucosabarrierének és a vese homeosztázisának fenntartásában, valamint a thrombocytaaggregációban játszanak szerepet. A nemszelektív NSAID-ok döntően a COXI enzimet gátolják, és csak kisebb mértékben a COX2-t. Ebből következik, hogy használatuk előtt minden esetben elsőként a GI és a renalis rizikó felmérését kell elvégezni [20]. Amennyiben a beteg nem tartozik egyik rizikócsoportba sem, és rövid ideig tartó NSAID-kezelésre szorul, általában nemszelektív NSAID adását javasoljuk. Miután a klinikai vizsgálatok alapján az egyes készítmények között effektivitásukban nincs szignifikáns különbség, az ajánlások sem szabják meg, hogy az orális nemszelektív NSAID-ok közül melyik hatóanyagot válasszuk a beteg számára [8]. Amennyiben a beteg krónikus NSAID-szedésre kényszerül az alapbetegsége miatt, a legfontosabb, hogy a gastroduodenalis szövődmények rizikóját felmérjük. A nemszelektív NSAID-ok használata mellett előforduló GI szövődmények rizikója magasabb a 65 év feletti populációban, antikoaguláns terápia (aszpirin, warfarin, alacsony molekulasúlyú heparin, direkt trombininhibitor, Xa-faktor és klopidogrél) adása mellett, korábbi GI vérzés, aktív peptikus fekély és egyidejü orális szteroid használata mellett. Az idős életkor önmagában négyszeres rizikót jelent a GI vérzés előfordulására [21]. A nemszelektív NSAID mellett előforduló GI adverz események minimalizálására a gastroprotectiv szerek (protonpumpagátló [PPI], H2-receptor-blokkoló) egyidejű alkalmazása ad lehetőséget, vagy COX2 szelektív NSAID-ra való áttérés. Az utóbbi esetben azonban mérlegre kell tennünk a GI rizikófaktorok mellett a $\mathrm{CV}$ rizikót is [20]. Az NSAID-ok nephrotoxicitasának hátterében fokozott renalis vasoconstrictio és következményes veseperfúzió-csökkenés áll. Az Amerikai Geriátriai Társaság így $30 \mathrm{ml} / \mathrm{min}$ alatti kreatininclearence esetében nem javasolja az NSAID-ok használatát [22]. A CV rizikót illetően nemcsak a szelektív COX2-inhibitorok mellett, hanem a nemszelektív NSAID-ok alkalmazásakor is magasabb rizikóval kell számolnunk. Amennyiben a betegnek nincs CV betegsége, azonban tartós, hoszszabb idejü NSAID-kezelésre szorul, az ajánlások a naproxén adását preferálják. Akut CV esemény bekövetkeztekor lehetőség szerint egyáltalán nem javasolt NSAID adása. Amennyiben magas CV rizikójú a beteg, vagy preventív aszpirinkezelésben részesül, az ajánlások a fentebb részletezett COX2 szelektív celekoxibot részesítik előnyben. Amennyiben a preventív aszpirinkezelés mellett rövid távú kezelésre nemszelektív NSAID-ot javaslunk, akkor érdemes az aszpirin bevételét 2 órával előbbre ter- vezni a lehetséges gyógyszer-interakciók miatt. A folyamat feltételezett mechanizmusa az, hogy a nemszelektív NSAID-ok leszorítják az aszpirint a COXl-kötő helyekről, így az nem képes a COXl acetilációjára, aminek eredményeképpen nem tud létrejönni a thrombocyták irreverzibilis COXl-inhibíciója. Ez a farmakodinámiai interakció a celekoxib és diklofenák esetében nem figyelhető meg, ibuprofénnel ellentmondóak a vizsgálatok eredményei, de a dózis csökkentésével egyértelmúen megelőzhető $[23,24]$.

Sok szó esett arról, hogy a mellékhatások csökkentésének egyik módja az, és az ajánlásokban is az szerepel, hogy a lehető legkisebb dózisokat alkalmazzuk az adott NSAID-ból. Ilyenkor azonban gyakran szembesülhetünk ineffektivitással. Az ibuprofén racem elegyében lévő, jobbra forgató változat és farmakológiailag aktív metabolit, a tiszta dexibuprofént tartalmazó gyógyszer elóállítása lehetővé tette, hogy a nemszelektív NSAIDok közül is egy sokkal hatékonyabb, ugyanakkor kevesebb mellékhatással rendelkező készítményt tudjunk ajánlani a betegeknek. A kedvező tolerálhatóság miatt az utóbbi években a dexibuprofén lett az NSAID-szerek közötti összehasonlítás alapja [25]. Összesen 6 klinikai és farmakovigilanciás vizsgálatban részt vevő 9000 beteg kezelése során nyert adatok meanalízise azt mutatta, hogy a CV biztonságossági profilja nagyon kedvező. A dexibuprofént $(800 \mathrm{mg} / \mathrm{nap})$ celekoxibbal $(2000 \mathrm{mg} /$ nap) összehasonlító vizsgálatban a dexibuprofén mellett egyetlen kedvezőtlen CV esemény sem fordult elö, szemben a celekoxibcsoportban talált 1,35\%-os aránnyal [26]. Az Európai Gyógyszerészeti Ügynökség (EMA) frissített ajánlása szerint a dexibuprofén legfeljebb napi 600 mg-os dózisának alkalmazása mellett nem tapasztalható a CV kockázat növekedése, így biztonsággal használható. A dexibuprofén $1200 \mathrm{mg}$ feletti napi dózisa mellett már hasonló kockázatnövekedést figyelhetünk meg, mint az ibuprofén $2400 \mathrm{mg}$ feletti dózisa esetén, és ez a CV kockázat hasonló mértékú, mint egyéb NSAIDok (COX2-gátlók vagy diklofenák) alkalmazásakor [27]. A GI adverz események előfordulását is több összehasonlító vizsgálatban alacsonyabbnak találták az ibuprofénhez képest. Egy posztmarketing, 7337 beteget involváló vizsgálatban a dexibuprofén és ibuprofén mellett alacsonyabb volt a GI események előfordulása (OR: 1,57), mint a naproxén (OR: 2,31 ), a piroxikám (OR: 2,63) vagy az aceklofenák/diklofenák (OR: 3,37) mellett [26].

\section{Megbeszélés}

A sok évtizedes klinikai praxisban szerzett tapasztalat, a számos obszervációs és randomizált kontrollált vagy posztmarketing vizsgálat eredményei ellenére sajnos még mindig vannak kérdéses pontok; hiányosak az adatok az NSAID-ok biztonságos használatáról, így a klinikai döntéshozatal ma is igen nehéz. Az NSAID-kezelésre várományos mozgásszervi fájdalomban és/vagy gyulla- 
dásos reumatológiai betegségben szenvedők gyakran magas rizikót hordoznak a társuló komorbiditások vagy előrehaladott életkoruk miatt. Az érvényben lévő ajánlások vezérfonalként szolgálnak, de a beteg összes klinikai aspektusát áttekintve, sokszor egyedi döntéshozatalra kényszerülünk. Amennyiben a beteg NSAID-kezelése indokolt, és semmilyen rizikócsoportba nem tartozik, a legalacsonyabb effektív dózisú NSAID-ot kell választani az első vonalban, lehetőség szerint a gazdaságossági szempontokat is figyelembe véve. Miután előfordul, hogy egy beteg nem ugyanúgy reagál az egyes, különböző hatóanyagú NSAID-okra, így hatástalanság esetén másik szerre is átválthatunk. Amennyiben nem csak rövid távú, átmeneti NSAID-használat válik szükségessé, rendkívül fontos a páciens megfelelő ellenórzése a potenciális toxicitas kiszúrése érdekében. Az alapellátásban monitorozni kell a vese- és májfunkciós paramétereket, a beteg vérképét és vérnyomását. Amennyiben a beteg cardioprotectiv célból aszpirint szed, lehetôség szerint kerülni kell az NSAID-ok használatát. Ha mégis szükséges, akkor PPI-védelemben adható a GI vérzések magasabb rizikója miatt. Amennyiben a beteg $\mathrm{CV}$ rizikója emelkedett, mind a szelektív, mind a nemszelektív NSAID-ok hordoznak további additív CV rizikót. Ilyen esetekben intermittálóan, alacsony dózisban adva a legkisebb rizikóval rendelkező NSAID-ot érdemes adni (naproxén, dexibuprofén), és így elkerülhető az aszpirin antikoaguláns hatásával történő interakció. Egyéb antikoaguláns terápia alkalmazása mellett a nemszelektív NSAID-ok alkalmazása kerülendő a GI vérzés fokozott veszélye miatt. A GI rizikófaktorok jelenléte esetén az NSAID-kezelés mellett preventív PPI-kezelést kell alkalmazni. Veseelégtelenségben nem szabad NSAID-ot használni, míg májfunkciós eltérések esetén is fokozott óvatosság ajánlott.

Anyagi támogatás: A közlemény megírása anyagi támogatásban nem részesült.

A szerző a cikk végleges változatát elolvasta és jóváhagyta.

Érdekeltségek: A szerzőnek nincsenek érdekeltségei.

\section{Irodalom}

[1] Wongrakpanich S, Wongrakpanich A, Melhado K, et al. A comprehensive review of non-steroidal anti-inflammatory drug use in the elderly. Aging Dis. 2018; 9: 143-150.

[2] Vane JR, Botting RM. Mechanism of action of non-steroidal anti-inflammatory drugs. Am J Med. 1998; 104: 2S-8S.

[3] Szamosi S. Application of topical non-steroid anti-inflammatory drugs in rheumatological pain management. [A topikus nem szteroid gyulladásgátló helye a reumatológiai fájdalomcsillapításban.] Magy Reumatol. 2017; 58: 20-24. [Hungarian]

[4] American College of Rheumatology Ad Hoc Group on Use of Selective and Nonselective Nonsteroidal Antiinflammatory Drugs. Recommendations for the use of selective and nonselective nonsteroidal antiinflammatory drugs: an American College of Rheumatology White paper. Arthritis Rheum. 2008; 59: 1058-1073.

[5] Verbeeck RK, Richardson CJ, Blocka KL. Clinical pharmacokinetics of piroxicam. J Rheumatol. 1986; 13: 789-796.

[6] Balding L. The World Health Organisation analgesic ladder: its place in modern Irish medical practice. Ir Med J. 2013; 106: 122-124.

[7] Meara AS, Simon LS. Advice from professional societies: appropriate use of NSAIDs. Pain Med. 2013; 14(Suppl 1): S3-S10.

[8] Burmester G, Lanas A, Biasucci L, et al. The appropriate use of non-steroidal anti-inflammatory drugs in rheumatic disease: opinions of multidisciplinary European expert panel. Ann Rheum Dis. 2011; 70: 818-822.

[9] Simon LS, Weaver AL, Graham DY, et al. Anti-inflammatory and upper gastrointestinal effects of celecoxib in rheumatoid arthritis: a randomized controlled trial. JAMA 1999; 282: 1921-1928.

[10] Silverstein FE, Faich G, Goldstein JL, et al. Gastrointestinal toxicity with celecoxib vs nonsteroidal anti-inflammatory drugs for osteoarthritis and rheumatoid arthritis: the CLASS study. A randomized controlled trial. Celecoxib Long-term Arthritis Safety Study. JAMA 2000; 284: 1247-1255.

[11] Sheng H, Shao J, Kirkland SC, et al. Inhibition of human colon cancer cell growth by selective inhibition of cyclooxygenase-2. J Clin Invest. 1997; 99: 2254-2259.

[12] Morales DR, Lipworth BJ, Guthrie B, et al. Safety risks for patients with aspirin-exacerbated respiratory disease after acute exposure to selective nonsteroidal anti-inflammatory drugs and COX-2 inhibitors: Meta-analysis of controlled clinical trials. J Allergy Clin Immunol. 2014; 134: 40-45.

[13] Cheng Y, Austin SC, Rocca B, et al. Role of prostacyclin in the cardiovascular response to thromboxane A2. Science 2002; 296: 539-541.

[14] McGettigan P, Henry D. Cardiovascular risk and inhibition of cyclooxygenase: a systematic review of the observational studies of selective and nonselective inhibitors of cyclooxygenase 2 . JAMA 2006; 296: 1633-1644.

[15] Hippisley-Cox J, Coupland C. Risk of myocardial infarction in patients taking cyclo-oxygenase- 2 inhibitors or conventional non-steroidal anti-inflammatory drugs: population based nested case-control analysis. BMJ 2005; 330: 1366.

[16] Coxib and traditional NSAID Trialists' (CNT) Collaboration, Bhala N, Emberson J, Merhi A, et al. Vascular and upper gastrointestinal effects of non-steroidal anti-inflammatory drugs: metaanalyses of individual participant data from randomised trials. Lancet 2013; 382: 769-779.

[17] Nissen SE, Yeomans ND, Solomon DH, et al. Cardiovascular safety of celecoxib, naproxen, or ibuprofen for arthritis. N Engl J Med. 2016; 375: 2519-2529.

[18] Schjerning Olsen AM, Fosbøl EL, Lindhardsen J, et al. Duration of treatment with nonsteroidal anti-inflammatory drugs and impact on risk of death and recurrent myocardial infarction in patients with prior myocardial infarction: a nationwide cohort study. Circulation 2011; 123: 2226-2235.

[19] Cannon CP, Curtis SP, FitzGerald GA, et al. Cardiovascular outcomes with etoricoxib and diclofenac in patients with osteoarthritis and rheumatoid arthritis in the Multinational Etoricoxib and Diclofenac Arthritis Long-term (MEDAL) programme: a randomised comparison. Lancet 2006; 368: 1771-1781.

[20] Rostom A, Dube C, Wells G, et al. Prevention of NSAID-induced gastroduodenal ulcers. Cochrane Database Syst Rev. 2002; 4: CD002296.

[21] Sabzwari SR, Qidwai W, Bhanji S. Polypharmacy in elderly: a cautious trail to tread. J Pak Med Assoc. 2013; 63: 624-627.

[22] Ungprasert P, Cheungpasitporn W, Crowson CS, et al. Individual non-steroidal anti-inflammatory drugs and risk of acute kidney injury: a systematic review and meta-analyses of observational studies. Eur J Intern Med. 2015; 26: 285-291. 
[23] Capone ML, Sciulli MG, Tacconelli S, et al. Pharmacodynamic interaction of naproxen with low-dose aspirin in healthy subjects. J Am Coll Cardiol. 2005; 45: 1295-1301.

[24] Farkouh ME, Greenberg JD, Jeger RV, et al. Cardiovascular outcomes in high risk patients with osteoarthritis treated with ibuprofen, naproxen or lumiracoxib. Ann Rheum Dis. 2007; 66: 764-770.

[25] Hodinka L, Bálint G, Budai E, et al. Peroral and transdermal application of non-steroidal anti-inflammatory drugs (NSAIDs) for the treatment of regional musculoskeletal pain syndromes. [Nem szteroid gyulladáscsökkentők peroralis és transdermalis alkal- mazása regionális mozgásszervi fájdalmi szindrómákban.] Orv Hetil. 2017; 158(Suppl 3): 3-30. [Hungarian]

[26] Archetti M. Tollerabilità dei FANS: recenti acquisizioni. Diseases \& Drugs 2013; Numero 5, Septembre/Ottobre.

[27] European Medicines Agency. Updated advice on use of high dose ibuprofen. EMA 325007/2015, 22 May 2015.

(Szamosi Szilvia dr., Debrecen, Nagyerdei krt. 98., 4032 e-mail: szamosi.szilvi@gmail.com)

\title{
MEGHÍVó
}

A Magyar Parazitológusok Társasága tisztelettel meghívja Önt

\author{
a II. Magyar Parazitológiai Workshop*-ra, melyet \\ A parazito-zoonózisok és oktatásuk az orvostudományi egyetemeken \\ („Docendo discimus"/Seneca/) címmel rendez. \\ Időpont: 2018. november 21. (szerda) 10 óra \\ Helyszín: Magyar Természettudományi Múzeum, Semsey terem \\ Budapest VIII., Ludovika tér 2-6.
}

\section{Bevezetés}

Prof. Dr. Kónya József (Debreceni Egyetem ÁOK, Orvosi Mikrobiológiai Intézet, Debrecen): Levél a Magyar Parazitológusok Társaságához

\section{Vitaindító előadás}

Dr. Kucsera István parazitológus szakorvos (Országos Közegészségügyi Intézet, Parazitológiai Osztály, Budapest): A Magyarországon leggyakrabban előforduló parazito-zoonózisokról

\section{Helyzetelemzések}

Dr. Palkovics Tamás szakorvos (Pécsi Tudományegyetem, Orvosi Mikrobiológiai és Immunitástani Intézet, Pécs)

Dr. Dóczi Ilona adjunktus (Szegedi Tudományegyetem, Szent-Györgyi Albert Klinikai Központ, Klinikai Mikrobiológiai Diagnosztikai Intézet, Szeged)

Dr. Burián Katalin (Szegedi Tudományegyetem ÁOK, Orvosi Mikrobiológiai és Immunbiológiai Intézet, Szeged)

Dr. Ghidán Ágoston adjunktus (Semmelweis Egyetem, Orvosi Mikrobiológiai Intézet, Budapest)

A rendezvényen való részvétel ingyenes, de regisztrációhoz kötött.

Regisztrálni a doczi.ilona@med.u-szeged.hu e-mail címen lehet.

A regisztráció határideje: 2018. november 14.

${ }^{*}$ A rendezvény támogatója a Boehringer Ingelheim RCV Magyarországi Fióktelepe, Állategészségügy

A cikk a Creative Commons Attribution-NonCommercial 4.0 International License (https://creativecommons.org/licenses/by-nc/4.0) feltételei szerint publikált Open Access közlemény, melynek szellemében a cikk nem kereskedelmi célból bármilyen médiumban szabadon felhasználható, megosztható és újraközölhető, feltéve, hogy az eredeti szerző és a közlés helye, illetve a CC License linkje és az esetlegesen végrehajtott módosítások feltüntetésre kerülnek. 